\title{
Persepsi Masyarakat Cirebon Terhadap Elemen Fisik Perkotaan di Koridor Jalan Cipto Mangunkusumo
}

\author{
Tedy Hartino Runny ${ }^{1}$, Farhatul Mutiah ${ }^{2}$ \\ ${ }^{1}$ Progam Studi Arsittektur, Sekolah Tinggi Teknologi Cirebon, Cirebon \\ Email: teddyhartino@gmail.com
}

\begin{abstract}
ABSTRAK
Jalan Cipto Mangunkusumo merupakan salah satu daerah pusat aktivitas kegiatan masyarakat Kota Cirebon, Letaknya yang strategis, pada pusat kota Cirebon sehingga menjadi jalur utama lalu lintas. Namun, ada beberapa elemen kota yang pemanfaatannya kurang sesuai sehingga fungsi elemen kota tersebut kurang maksimal dan menimbulkan ketidaknyamanan masyarakat yang beraktivitas atau melintasi jalan tersebut. Untuk mengetahui persepsi masyarakat, maka dilakukan penelitian dengan menggunakan teori Hamid Shirvani, yang menjelaskan 8 elemen fisik pembentuk kota, yaitu : penggunaan lahan (Land Use), bentuk dan massa bangunan (Building Form and Massing), sirkulasi dan parking (Circulation and Parking), ruang terbuka (Open Space), jalur pejalan kaki (Pedestrian Ways), papan penanda (Signages), pendukung aktivitas (Activity Support), preservasi (Preservation). Adapun metode yang digunakan adalah metode kualitatif dengan pengambilan data kuesioner secara online kepada 116 responden yang diambil secara random sampling. Maksud pengambilan sampling kepada responden tersebut yaitu untuk mendapatkan persepsi masyarakat mengenai kesesuaian dan kurang kesesuaian 8 elemen fisik pembenetuk kota yang ada di koridor Jalan Cipto Mangunkusumo. Hasil menunjukan persepsi masyarakat pada elemen fisik kota yang sudah sesuai adalah : penggunaan lahan, bentuk dan massa bangunan, jalur pejalan kaki, papan penanda serta preservasi, Sedangkan yang kurang sesuai adalah: sirkulasi dan area parkir, ruang terbuka serta ruang pendukung aktivitas..
\end{abstract}

Kata kunci : elemen fisik kota, kenyamanan kota, koridor jalan, pusat aktivitas.

\section{ABSTRACT}

Jalan Cipto Mangunkusumo is one of the central areas for community activities in Cirebon City. It is strategically located in the city center so that it becomes the main traffic lane in Cirebon City. However, there are some elements of the city whose utilization is not suitable so that the function of the urban elements in the area is not optimal and causes inconvenience to people who are active or crossing the road. With the public perception of the physical elements of the city in the corridor of the road, this study uses Hamid Shirvani's theory, this theory is a theory that explains the 8 physical elements that make up a city, these elements include: land use, shape and building mass (Building Form and Massing), circulation and parking (Circulation and Parking), open space (Open Space), pedestrian paths (Pedestrian Ways), signages (Signages), activity support (Activity Support), preservation (Preservation). From the indicators of 8 physical elements that make up the city, the method used in this study is to use qualitative methods by taking online questionnaire data to 116 respondents who were taken by random sampling. The purpose of taking sampling of these respondents is to obtain conclusion data about people's perceptions of suitability and lack of conformity to the 8 physical elements that make up the city in the corridor of Jalan Cipto Mangunkusumo, among community perceptions on the physical elements of the city that are appropriate, among others: land use, the shape and mass of buildings, pedestrian paths, signboards, preservation, and people's perceptions of the physical elements of the city that are not suitable, including: circulation and parking areas, open spaces, space to support activities.

Keywords: . physical elements of the city, city convenience, road corridors, activities centre 


\section{PENDAHULUAN}

Kenyamanan masyarakat terhadap fasilitas kota merupakan hal yang mendasar dan harus diutamakan keberadaanya. Jalan Cipto Mangunkusumo di Kota Cirebon merupakan salah satu jalan arteri kota dan menjadi simpul pergerakan aktivitas bagi masyarakat Kota Cirebon. Menurut data Badan Pusat Statistik (BPS) Kota Cirebon Tahun 2018 jumlah kendaraan pada tahun sebelumnya dari tahun 2016 ke tahun 2017 meningkat menjadi 6,01\% atau 11.500 unit kendaraan yang melintasi Kota Cirebon,seperti terlihat pada tabel 1 di bawah ini [1]:

Tabel 1. Jumlah Kendaraan

\begin{tabular}{ccccc} 
No & $\begin{array}{c}\text { Jenis } \\
\text { Kendaraan }\end{array}$ & $\begin{array}{c}\mathbf{2 0 1 5} \\
\text { (unit) }\end{array}$ & $\begin{array}{c}\mathbf{2 0 1 6} \\
\text { (unit) }\end{array}$ & $\begin{array}{c}\mathbf{2 0 1 7} \\
\text { (unit) }\end{array}$ \\
\hline 1 & Sepeda Motor & 139.621 & 147.861 & 157.014 \\
\hline 2 & Mobil Penupang & 27.559 & 29.017 & 30.997 \\
\hline 3 & Mobil Barang & 14.030 & 14.435 & 14.802 \\
\hline \multirow{2}{*}{ Sumber : BPS Kota Cirebon Tahun 2018 [1] } & Jumlah & $\mathbf{1 7 5 . 9 3 5}$ & $\mathbf{1 9 1 . 3 1 3}$ & $\mathbf{2 0 2 . 8 1 3}$
\end{tabular}

Semakin meningkat aktivitas perkotaan maka semakin padat pula pergerakan kegiatan masyarakat terutama yang ada di perkotaan, seperti halnya di Jalan Cipto Mangunkusumo. Namun ada beberapa elemen kota yang pemanfaatan fungsinya belum sesuai, seperti halnya pemanfaatan trotoar. Saat ini trotoar digunakan oleh pedagang kaki lima, tempat tongkrongan ojek online. Selain itu parkir kendaraan yang tidak sesuai tempatnya dan pengaturan lalu lintas oleh oknum yang tidak bertangung jawab tersebut memberi dampak pada pergerakan aktivitas masyarakat di lokasi ataupun yang melintasi jalan tersebut. Apabila hubungan pergerakan aktivitas dan penggunaan elemen fisik perkotaan sesuai maka akan tercipta citra kota yang nyaman. Studi ini akan meneliti tentang persepsi masyarakat terhadap elemen fisik perkotaan yang ada di koridor jalan Cipto Mangunkusumo Cirebon.

\section{METODOLOGI}

Metoda yang digunakan pada penelitian ini adalah metoda kualitatif. Metoda ini digunakan untuk mengetahui respon dan persepsi masyarakat terhadap elemen fisik perkotaan di Koridor Jalan Cipto Mangunkusumo. Langkah awal adalah mempelajari sejarah kawasan dan tahapan pembangunan yang telah dilakukan di Koridor Jalan Cipto Mangunkusumo. Langkah berikutnya adalah menyebarkan kuesioner terhadap 116 responden yang mengerti situasi dan kondisi di Jalan tersebut, yang terdiri dari \pm 40 orang yang setiap harinya beraktivitas di Kawasan Koridor Jalan Cipto Mangunkusumo dan \pm 60 Orang yang hanya melewati Koridor Jalan Cipto Mangunkusumo. Selain itu dilakukan pula observasi ke lapangan untuk mengobservasi dan merekam data-data untuk mengetahui kondisi elemen kota. Hasil observasi dan kuestioner kemudian di analisis untuk menjawab permasalahan yang ada saat ini.

\subsection{Rumusan Masalah}

Berdasarkan latar belakang yang telah dijelaskan maka dapat dirumuskan permasalahan sebagai berikut:

- Apa saja elemen fisik perkotaan yang ada di Koridor Jalan Cipto Mangunkusumo.

- Bagaimana memaksimalkan fungsi elemen fisik perkotaan yang ada di Jalan Cipto Mangunkusumo.

\subsection{Maksud dan Tujuan}

- Mengetahui apa saja elemen fisik pembentuk kota di Koridor Jalan Cipto Mangunkusumo.

- Merumuskan langkah langkah untuk meningkatkan kegunaan fungsi elemen fisik perkotaan yang terdapat di Jalan Cipto Mangunkusumo. 


\subsection{Teknik Pengumpulan Data}

Teknik pengumpulan data merupakan langkah penting dalam menjalankan proses penelitian agar memperkuat kebenaran tentang pembahasan. Terdapat dua cara pengumpulan data dalam penelitian ini, yaitu:

- Data Primer

Teknik pengumpulan data primer yaitu dengan cara terjun ke lapangan untuk membuat gambar/ sketasa dan dokumentasi terkait situasi dan kondisi elemen fisik perkotaan yang ada di Jalan Cipto Mangunkusumo.

- Data Sekunder

Teknik pengumpulan data sekunder yaitu dengan mempelajari data dari berbagai sumber, dari literature, media ataupun instansi pemerintahanan dan dari responden melului kuesioner. Menurut Sugiyono dalam buku Metode Penelitian Pendidikan (2016:199), "Kuesioner merupakan teknik pengumpulan data yang dilakukan dengan cara memberikan seperangkat pertanyaan atau pernyataan tertulis kepada responden untuk dijawabnya" [2].

\subsection{Kajian Teori}

Untuk menciptakan Citra Kota yang baik dan nyaman terdapat beberapa elemen-elemen pembentuk kota. Menurut Hamid Shirvani, 1985 dalam bukunya "Urban Design Process" terdapat delapan macam elemen yang membentuk sebuah kota (terutama pusat kota), yaitu [3]:

\section{Land Use}

Prinsip Land Use adalah pengaturan penggunaan lahan untuk menentukan pilihan yang terbaik dalam mengalokasikan fungsi tertentu, sehingga pengaturan pembagian zona kawasan pada sebuah kota tepat pada fungsinya. Land Use merupakan pemanfaatan atau kegunaan dari suatu lahan, terdapat berbagai macam dan jenis aktivitas yang berlangsung di dalamnnya (Marler : 1985) [4]. Tata Guna Lahan merupakan rancangan pembagian kawasan berupa zonasi peruntukan lahan sebuah kota, ruang-ruang lahan akan diatur sesuai dengan fungsi lahan tersebut. Sebagai contoh, di dalam zona kawasan permukiman di sebuah kota maka di area lahan tersebut diatur sebagai kawasan permukiman atau di dalam kawasan perekonomian maka penggunaan lahan diarea tersebut diatur sebagai lahan area komersial dan di dalam kawasan pemerintahan maka di area lahan tersebut diatur sebagai bangunan perkantoran pemerintah. Kebijaksanaan tata guna lahan juga membentuk hubungan antara sirkulasi/ parkir dan kepadatan aktivitas masyarakat.

\section{Building Form and Massing}

Bentuk dan massa bangunan ditentukan oleh aturan regulasi daerah tersebut, aturan tersebut meliput tinggi dan besarnya bangunan, KDB, KLB, sempadan, skala, material, warna, dan sebagainya. Prinsip-prinsip dan teknik Urban Design yang berkaitan dengan bentuk dan massa bangunan antara lain:

- Skala, yang berkaitan dengan sudut pandang manusia, sirkulasi, dan dimensi bangunan sekitar.

- Ruang Kota, seperti sirkulasi ruang yang disebabkan bentuk kota, batas, dan tipe-tipe ruang.

- Massa Kota, yang meliputi bangunan, permukaan tanah dan obyek yang tersusun dalam ruang kota untuk membentuk kawasan kota beserta pola aktifitas dalam skala besar dan kecil.

\section{Circulation and Parking}

Sirkulasi kota meliputi prasarana jalan yang tersedia, bentuk struktur kota, fasilitas pelayanan umum, dan tingkat kepadatan kendaraan di kawasan kota. Alur sirkulasi dapat diartikan sebagai "tali" yang mengikat ruang-ruang suatu bangunan atau suatu deretan ruang-ruang dalam maupun luar, menjadi saling berhubungan, seperti yang diungkap oleh Francis D.K. Ching, 1993. [5]. Semakin meningkatnya aktivitas kegiatan di sebuah kota maka semakin tinggi pula tingkat sirkulasinya, maka pada kawasan kota area parkir sangat dibutuhkan terutama di pusat-pusat kegiatan kota (CBD) guna untuk mendukung kegiatan dari semua aspek yang ada pada kota. Sirkulasi juga merupakan elemen perancangan kota yang secara langsung dapat membentuk dan mengkontrol pola kegiatan kota, sebagaimana halnya dengan keberadaan sistem transportasi dari 
jalan publik, pedestrian way, dan tempat-tempat transit yang saling berhubungan akan membentuk pergerakan (suatu kegiatan).

\section{Open Space}

Open space merupakan elemen dalam perancangan sebuah kota, erat kaitannya dengan fasilitas umum yang harus dimiliki dalam sebuah kawasan kota. Berbicara tentang ruang terbuka (open space) selalu menyangkut dengan rencana penyediaan lansekap, elemen lansekap terdiri dari elemen keras (hardscape seperti: jalan, trotoar, patung, bebatuan dan sebagainya) serta elemen lunak (softscape) berupa tanaman dan air. Menurut Yoshinobu Ashihara (1981)"ruang luar adalah ruang yang terjadi dengan membatasi alam". [6] Ruang terbuka biasa berupa lapangan, jalan, sempadan sungai, green belt, taman, alun-alum dan sebagainya. Sedangkan Audy Abdillah, 2017 mengatakan "Dalam perencanaan open space akan senantiasa terkait dengan perabot taman/ jalan (street furniture). Street furniture ini bisa berupa lampu, tempat sampah, papan nama, bangku taman dan sebagainya”.[7]

\section{Pedestrian Ways}

Elemen pejalan kaki erat interaksinya dengan elemen-elemen fisik pembentuk kota dan harus berkaitan dengan lingkungan kota serta pola-pola aktivitas sesuai dengan rencana perubahan atau pembangunan fisik kota di masa mendatang. Perubahan-perubahan rasio penggunaan, jalan raya yang dapat mengimbangi dan meningkatkan arus pejalan kaki dapat dilakukan dengan memperhatikan aspek pendukung aktivitas di sepanjang jalan dan Street Furniture.

\section{Signage}

Papan penanda digunakan untuk petunjuk jalan atau arah ke suatu kawasan tertentu pada sebuah kota, baik petunjuk arah ataupun penanda sebuah jalan dan papan tanda yang bertujuan bisnis ataupun komersil. Tanda yang didesain dengan baik akan menyumbangkan karakter pada fasade bangunan dan menghidupkan street space dan memberikan informasi bisnis atau komersial yang menarik pula sehingga dapat menciptakan citra kota yang mearik dan nyaman.

\section{Activity Support}

Pendukung kegiatan adalah semua fungsi bangunan atau area yang berfungsi untuk mendukung kegiatan-kegiatan yang berlangsung pada kawasan kota. Bentuk fasilitas pendukung kegiatan antara lain alun-alun, taman kota, taman rekreasi, taman budaya, perpustakaan, kawasan PKL, pedestrian dan sejenisnya. Ruang Publik adalah fungsi ruang untuk menampung aktivitas masyaraakat, baik secara individu maupun secara kelompok, dimana bentuk ruang publik ini sangat tergantung pada pola dan susunan massa bangunan (Hakim, 1987) [8]. Penataan terhadap aktivitas pendukung kegiatan akan sangat mempengaruhi visualisasi kota, baik secara makro maupun mikro, jika jumlahnya cukup banyak maka akan memiliki karakter yang berbeda pula. Sebagai contoh, jika banyak terdapat area fasilitas pendukung kegiatan dan tidak diatur perletakannya maka akan dapat menutupi fasade bangunan di sekitarnya. Dengan begitu, visual bangunan tersebut akan terganggu. Namun, jika dilakukan penataan dengan baik, ada kemungkinan penataan tersebut dapat menambah keindahan visual bangunan di sekitarnya.

\section{Preservation}

Preservasi dalam perancangan kota adalah perlindungan, perawatan maupun peningkatan terhadap lingkungan tempat tinggal (permukiman) dan urban places (alun-alun, plaza, area perbelanjaan) yang ada dan mempunyai ciri khas, seperti halnya perlindungan terhadap bangunan bersejarah. Ada beberapa manfaat dari kegiatan preservasi, seperti di kutip dari Rahnandahegar Ardin Adinugrah, 2013 yang mengatakan bahwa "Manfaat dari adanya preservasi yaitu Meningkatkan nilai lahan, meningkatkaan nilai lingkungan, menghindarkan dari pengalihan bentuk dan fungsi karena aspek komersial, menjaga identitas kawasan perkotaan dan meningkatkan pendapatan dari pajak dan retribusi”.'[9] 


\section{HASIL DAN PEMBAHASAN}

\subsection{Gambaran Umum}

\subsubsection{Letak Geografis}

Berdasarkan BPS (Badan Pusat Statistik) Kota Cirebon, Secara geografis Kota Cirebon terletak pada $108^{\circ} 33$ Bujur Timur dan $6^{\circ} 41$ Lintang Selatan pada pantai Utara Pulau Jawa, bagian timur Jawa Barat, dengan ketinggian $\pm 5 \mathrm{M}$ dari permukaan laut (ketinggian tersebut termasuk dataran rendah).

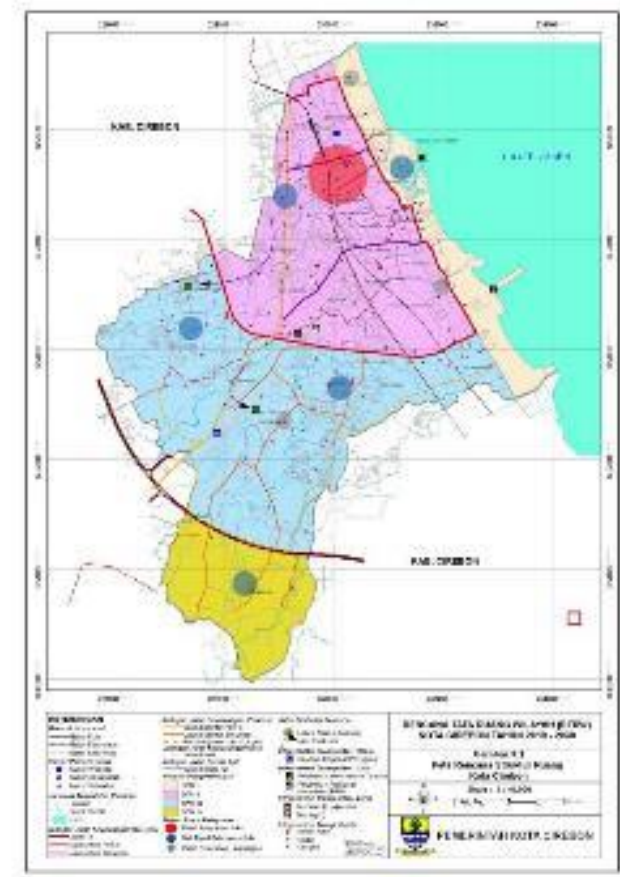

Gambar 1. Peta Kota Cirebon

Sumber : Pemerintah Kota Cirebon

Batasan-batasan Kota Cirebon, antara lain:

- Sebelah Utara : Sungai Kedung Pane

- Sebelah Barat : : Sungai Banjir Kanal

- Sebelah Selatan : : Sungai Kalijaga

- Sebelah Timur : Laut Jawa

\subsubsection{Wilayah}

Kota Cirebon memiliki luas wilayah administrasi $37,36 \mathrm{~km}^{2}$ yang terbagi kedalam lima kecamatan, yaitu: Harjamukti, Lemahwungkuk, Pekalipan, Kejaksaan dan Kesambi (Cirebon Dalam Angka, data BPS Tahun 2018). Keberadaan 3 Keraton, yaitu: Kasepuhan, Kanoman dan Kacirebonan dan warisan budaya berupa bangunan dan situs meningkatkan kunjungan ke kota Cirebon. Hal ini didukung dengan dibukanya jalan Tol darii Jakarta yang memudahkan wisatawan masuk ke kota Cirebon. Hal ini memicu meningkatnya aktivitas terutama di pusat kota terutama di Koridor Jalan Cipto Mangunkusumo.

\subsubsection{Lingkup Studi}

Lingkup studi pada penelitian ini yaitu pada lokasi Jalan Cipto Mangunkusumo, Kecamatan Kesambi, Kota Cirebon, yang meliputi area dari persimpangan Jalan Cipto - Pemuda sampai persimpangan Jalan Cipto - Kartini atau tepatnya dari KM 0 (perempatan Grage Mall) sampai dengan KM 1,7 (perempatan Cipto) [10]. 


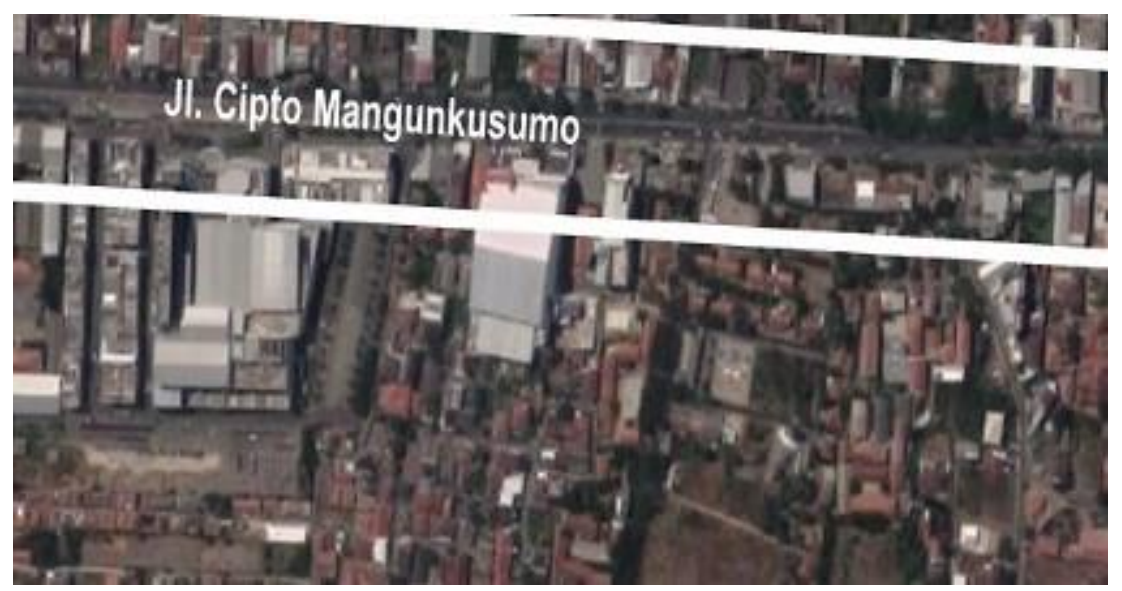

Gambar 2. Site Lokasi Penelitian

Sumber : Google Maps 2019

\subsection{Analisis Fisik Kondisi Bangunan}

Dari hasil indentifikasi di lapangan, kondisi fisik kawasan Koridor Jalan Cipto Mangunkusumo terdiri dari bangunan komersial, perkantoran, pendidikan, permukiman dan beberapa fasilitas publik yang juga menjadi unsur elemen fisik pembentuk kota. Kondisi bangunan disepanjang jalan sebagian besar bangunannya sudah memenuhi aturan regulasi RTRW Kota Cirebon, namun beberapa fasilitas publik penggunaannya masih kurang maksimal pemanfaatannya. Misalnya pemanfaatan pedestrian oleh PKL, trotoar sebagai tempat nongkrong driver ojek online, penjemput pekerja yang bekerja di kawasan tersebut dan beberapa fasilitas drainase yang belum maksimal sehingga sering terjadi banjir saat hujan dan menutupi sebagian besar ruas koridor jalan Cipto Mangunkusumo.

Kondisi lain yang dijumpai adalah sering terjadi kemacetan kendaraan pada jam-jam sibuk, seperti jam berangkat dan pulang kerja, weekend dan beberapa hari besar lainnya. Kemacetan tersebut menjadi salah satu unsur ketidaknyamanan masyarakat pengguna yang melintasi koridor tersebut. Frekwensi kemacetan terjadi hampir setiap hari kecuali pada hari-hari libur nasionnal sehingga analisis fisik kondisi kawasan koridor jalan tersebut berkaitan erat dengan persepsi masyarakat terhadap 8 elemen fisik pembentuk kota.
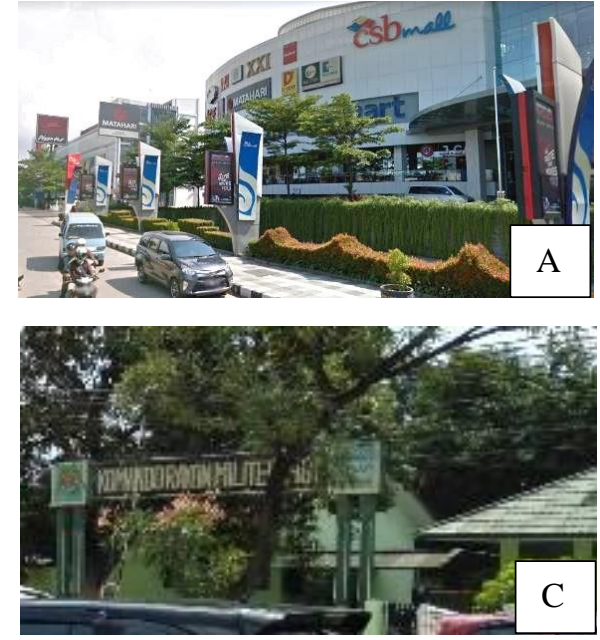
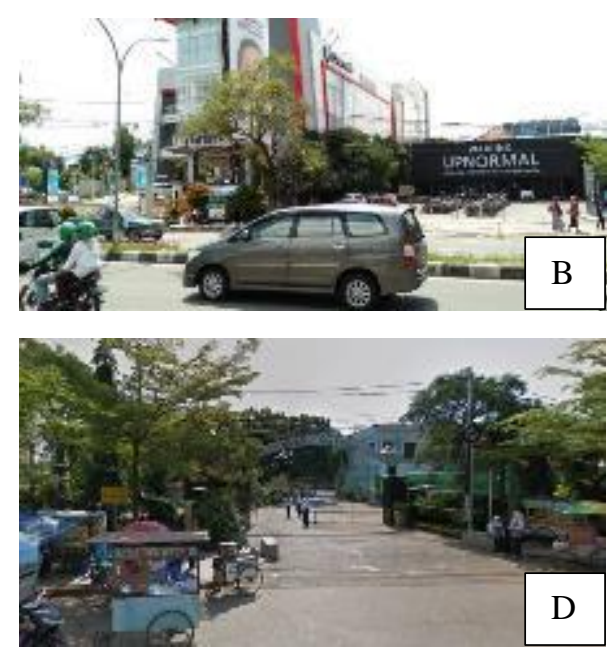

Gambar 3. [A] Bangunan Komersial di Koridor Jalan Cipto Mangunkusumo; [B] Bangunan Komersial di Koridor Jalan Cipto Mangunkusumo; [C] Bangunan Pemerintah di Koridor Jalan Cipto Mangunkusumo; [D] Bangunan Sekolah di Koridor Jalan Cipto Mangunkusumo Sumber : Hasil Survei 2019 


\subsection{Kondisi Jalan dan Fasilitas}

Dari hasil survey terkait kondisi jalan dan fasilitas di Koridor Jalan Cipto Mangunkusumo, ada beberapa hal yang masih belum tertata dengan baik, diantaranya:

1. Pengaturan pengalihan arus lalu lintas oleh oknum yang tidak bertanggung jawab. Kegiatan tersebut menghambat arus lalu lintas pengguna jalan karena harus menunggu kendaraan yang berputar balik. Hal ini terutama pada saat jam berangkat dan pulang kerja yang sangat mengganggu arus lalu lintas di koridor jalan tersebut.

2. Pemanfaatan jalur pedestrian oleh pedagang kaki lima, kegitan ini sama dengan mengambil hak pejalan kaki yang dapat berdampak terhadap kemacetnya arus lalu lintas.

3. Pemanfaatan trotoar sebagai tempat pemberhentian ojek online dan tempat nongkrong penjemput karyawan mall, juga menghambat arus lalu lintas pengguna jalan. Hal ini dikarenakan penumpukan kendaraan parkir yang menghambat kendaraan yang melintasi koridor jalan tersebut.
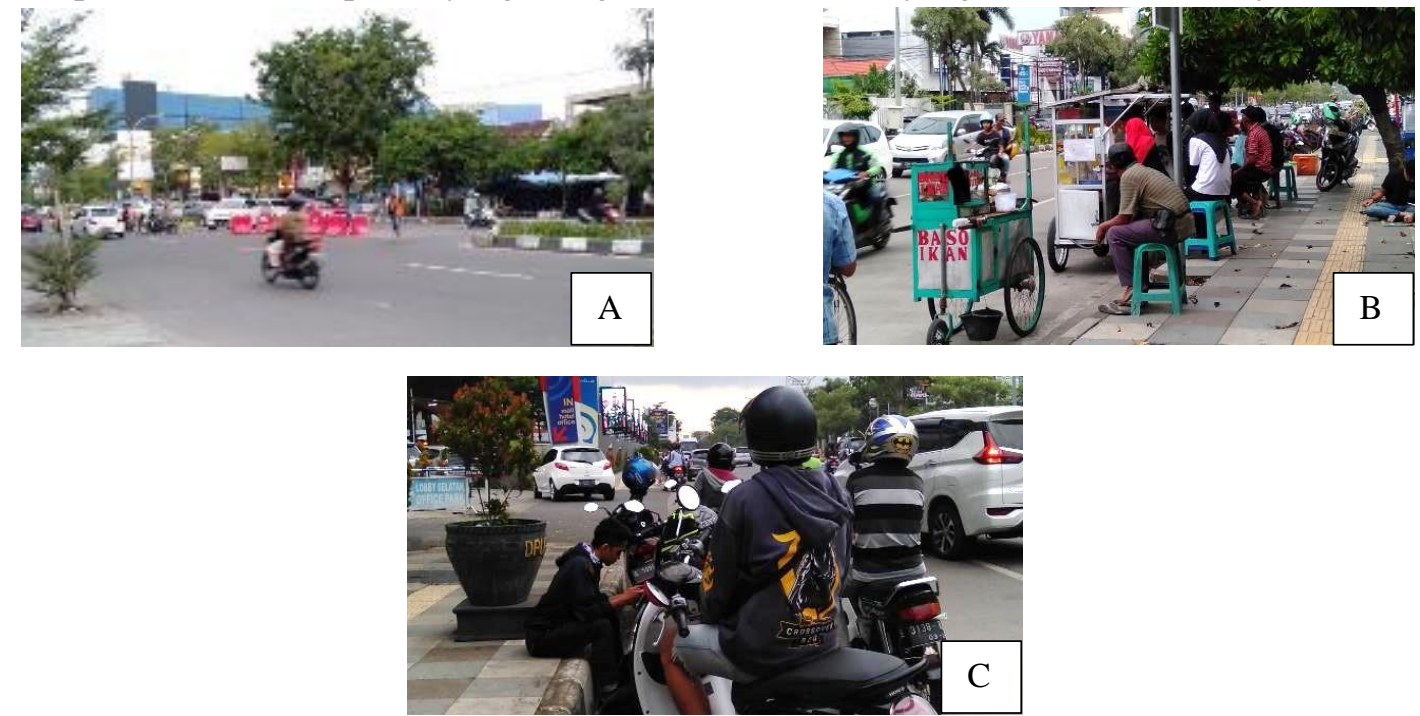

Gambar 3. [A] Pengaturan Arus Lalu Lintas Oleh Oknum; [B] Penggunaan Pedestrian Sebagai Tempat Pedagang Kaki Lima; [C] Pemanfaatan Pedestrian Sebagai Pemberhentian Kendaraan Bermotor

Sumber : Hasil Survei 2019

\subsection{Analisis Persepsi Masyarakat Cirebon}

Untuk menganalisisi persepsi masyarakat pada elemen fisik pembentuk kota yang ada di Koridor Jalan Cipto Mangunkusumo Kota Cirebon, maka diambil sample secara acak kepada 116 orang melalui metode kuesioner online yang berisi pertanyaan kepada masyarakat yang mengetahui tentang kondisi koridor jalan tersebut. Para responden terdiri dari masyarakat yang berdomisili di berbagai daerah:

- Kota Cirebon $(44,4 \%)$

- Kabupaten Cirebon $(48,2 \%)$

- Wilayah III Ciayumajakuning $(4,6 \%)$

- Diluar Wilayah Kota/ Kabupaten Cirebon dan Wilayah III Ciayumajakuning $(2,8 \%)$

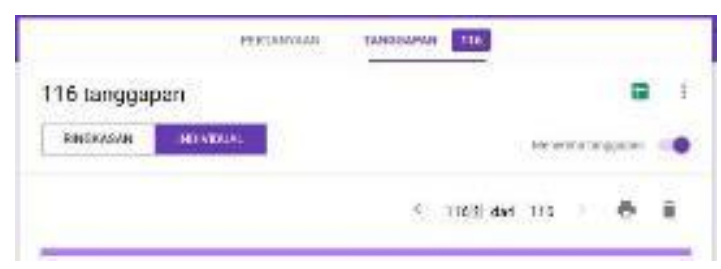

Gambar 10. Jumlah Masyarakat yang Memberi Pemberhentian Kendaraan Bermotor Sumber : Hasil Analisa 2019

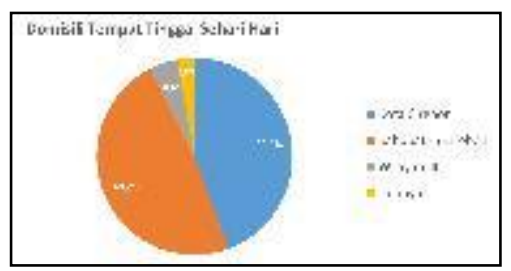

Diagram Pie 1. Domisili Populasi Masyarakat yang Memberi Tanggapan Sumber : Hasil Analisa 2019 
Pengambilan sampel juga mempertimbangkan mengenai berapa kali masyarakat melewati Koridor Jalan Cipto Mangunkusumo dalam kurun waktu 1 minggu. Pertimbangan tersebut untuk mengukur realita dan tanggapan yang diberikan terhadap persepsi mengenai elemen fisik kota yang ada di koridor jalan tersebut.

Parameter pengukuran antara lain:

- $\quad 5$ kali dalam 1 minggu $(50,9 \%)$

- 5 - 10 kali dalam 1 minggu $(28,7 \%)$

- 10 - 15 kali dalam 1 minggu $(8,3 \%)$

- $\quad>15$ kali dalam 1 minggu $(12,1 \%)$

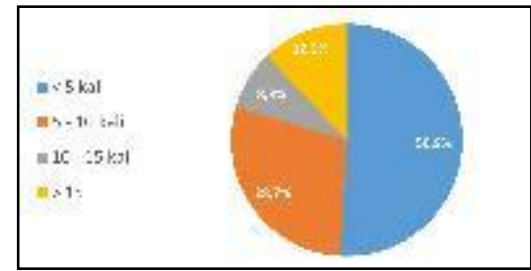

Diagram Pie 2. Persentase Masyarakat yang Melewati

Jalan Cipto Mangunkusumo

Sumber : Hasil Analisa 2019

Hasil kuesinoer menunjukan mayoritas masyarakat $<5$ kali melewati Koridor Jalan Cipto Mangunkusumo dalam kurun waktu 1 minggu. Hasil analisis dapat digambarkan sebagai berikut:

\section{Analisis Land Use}

Analisis persepsi masyarakat terhadap elemen penggunaan lahan (Land Use) yang ada di Koridor Jalan Cipto Mangunkusmo yaitu sebesar 61,2\% dari masyarakat berpendapat bahwa penggunaan lahan atau zonasi lahan perkotaan yang ada di koridor jalan tersebut sudah sesuai.

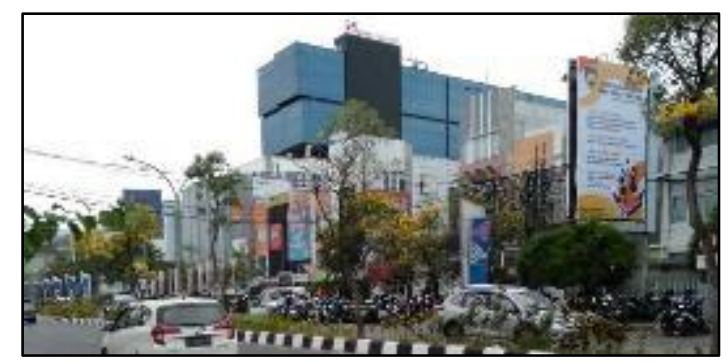

Gambar 11. Penggunaan lahan area komersil (sesuai) Sumber : Hasil Survei 2019

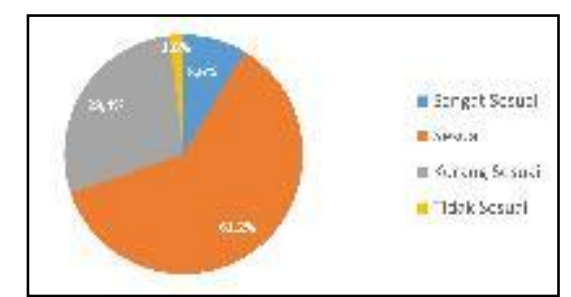

Diagram Pie 3. Persentase Masyarakat yang Memberi Tanggapan Tentang Land Use Sumber : Hasil Analisis 2019

Hasil tersebut didapat karena sebagian besar elemen penggunaan lahan dan pembagian zonasinya yang ada di Koridor Jalan Cipto Mangunkusumo sudah sesuai dengan RTRW Kota Cirebon seperti halnya penggunaan lahan komersial yang ada di koridor jalan tersebut.

\section{Analisis Building Form and Massing}

Analisis persepsi masyarakat terhadap bentuk dan massa bangunan (Building and Massing) yang ada di Koridor Jalan Cipto Mangunkusumo yaitu sebesar 67,2\% dari populasi masyarakat berpendapat bahwa bentuk dan masa bangunan yang ada di koridor jalan tersebut sudah sesuai. 


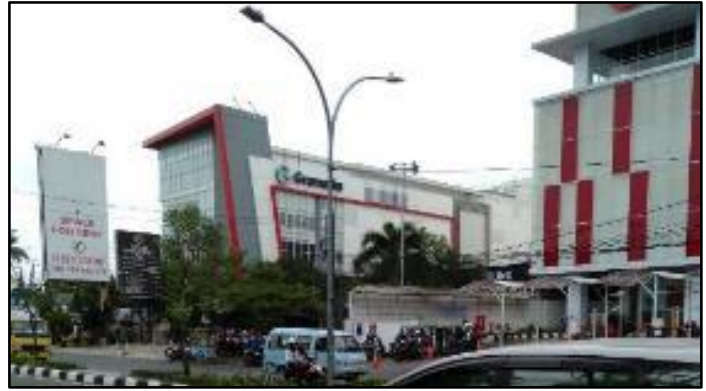

Gambar 12. Bentuk dan massa bangunan di Koridor Jalan Cipto Mangunkusumo Cirebon (sesuai) Sumber : Hasil Survei 2019

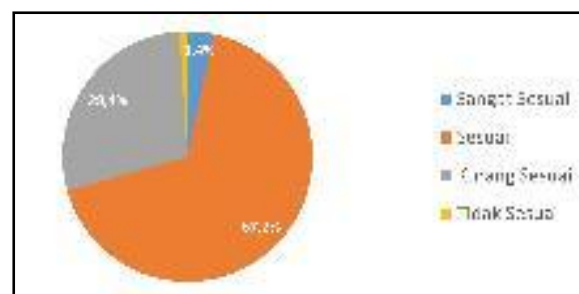

Diagram Pie 4. Persentase Masyarakat yang Memberi Tanggapan Tentang Building Form and Massing Sumber : Hasil Analisis 2019

Hasil tersebut didapat karena sebagian besar elemen bentuk dan massa bangunan yang ada di Koridor Jalan Cipto Mangunkusumo sudah sesuai dengan aturan regulasi RTRW Kota Cirebon seperti halnya KDB, KLB, GSP, GSB dan sejenisnya. Adapun pada bentuk atau tampilan secara estetika bangunan pada kawasan koridor tersebut juga sudah menarik karena koridor jalan tersebut merupakan jalan alternatif utama Kota Cirebon sehingga pengguna lahan yang ada disitu sebagian besar merencanakan bentuk dan massanya dengan baik.

\section{Analisis Circulation and Parking}

Analisis persepsi masyarakat terhadap sirkulasi dan area parkir (Circulation And Parking) yang ada di Koridor Jalan Cipto Mangunkusumo yaitu sebesar 56,9\% dari populasi masyarakat berpendapat bahwa sirkulasi dan penataan area parkir yang ada di koridor jalan tersebut kurang baik.

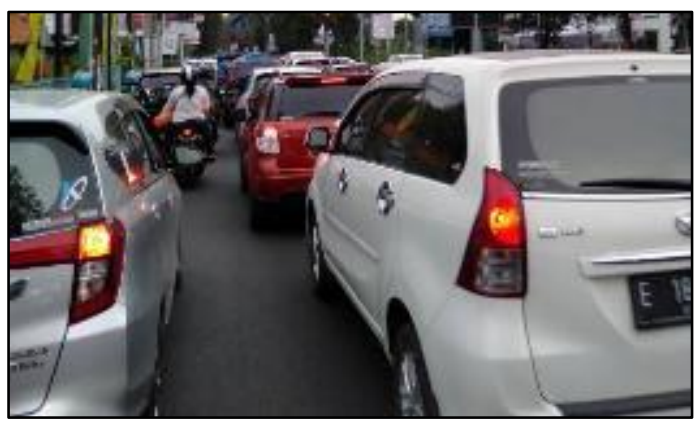

Gambar 13. Kepadatan sirkulasi di Koridor Jalan Cipto Mangunkusumo Cirebon (kurang baik) Sumber : Hasil Survei 2019

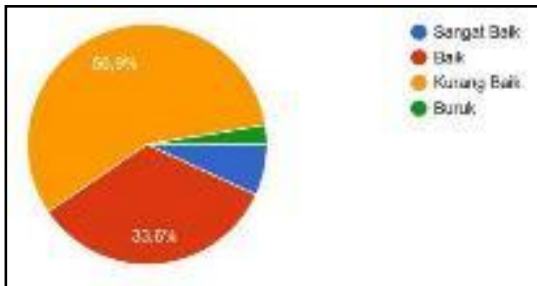

Diagram Pie 5. Persentase Masyarakat yang Memberi Tanggapan Tentang Circulation and Parking Sumber : Hasil Analisis 2019

Hasil tersebut didapat karena semakin meningkatnya masyarakat yang beraktivitas maupun melewati Koridor Jalan Cipto Mangunkusumo, meningkat pula kepadatan sirkulasi maupun area parkir pada koridor jalan tersebut. Oleh karenanya perlu penanganan khusus terhadap panataan area parkir dan sirkulasi di koridor jalan tersebut.

\section{Analisis Open Space}

Analisis persepsi masyarakat terhadap elemen ruang terbuka (Open Space) yang ada di Koridor Jalan Cipto Mangunkusumo yaitu sebesar 53,4\% dari populasi masyarakat berpendapat bahwa ruang terbuka yang ada di koridor jalan tersebut kurang baik. 


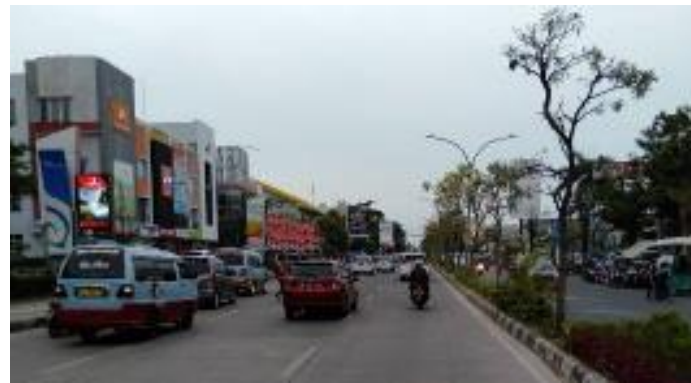

Gambar 14. Ruang terbuka di Koridor Jalan Cipto Mangunkusumo Cirebon (kurang baik) Sumber : Hasil Survei 2019

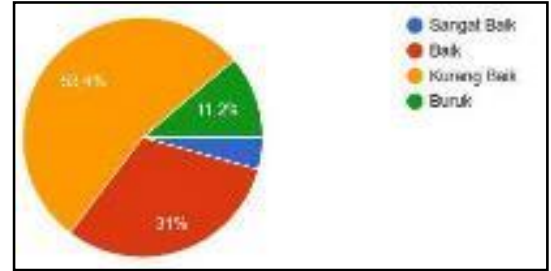

Diagram Pie 6. Persentase Masyarakat yang Memberi Tanggapan Tentang Open Space Sumber : Hasil Analisis 2019

Hasil tersebut didapat karena ketersediaan ruang publik seperti taman, halaman dan sejenisnya di Koridor Jalan Cipto Mangunkusumo belum tersedia secara memadai untuk memenuhi kebutuhan ruang publik yang semakin meningkat. Pada sisi lain koridor jalan tersebut merupakan jalan utama Kota Cirebon yang mempunyai potensi untuk meningkatkan kemajuan kota.

\section{Analisis Pedestrian Ways}

Analisis persepsi masyarakat terhadap elemen jalur pejalan kaki (Pedestrian Ways) yang ada di Koridor Jalan Cipto Mangunkusumo yaitu sebesar 48,1\% dari populasi masyarakat berpendapat bahwa jalur pedestrian yang ada di koridor jalan tersebut sudah baik.

Akan tetapi pada bagian tertentu kondisi jalur pejalan kaki masih ada yang belum maksimal seperti halnya jalur penggunaan jalur pejalan kaki untuk parkir kendaraan, tempat PKL. Bahkan di bagian tertentu yaitu di timur jalan masih ada beberapa jalur pejalan kaki yang rusak. Kondisi ini perlu mendapatkan perhatian guna untuk memaksimalkan kenyamanan masyarakat yang beraktivitas pada koridor jalan tersebut.

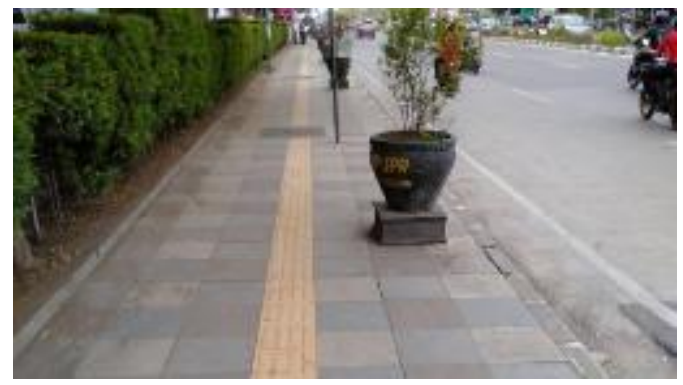

Gambar 15. Jalur Pejalan Kaki yang Sudah Diperbaiki (sudah baik) Sumber : Hasil Survei 2019

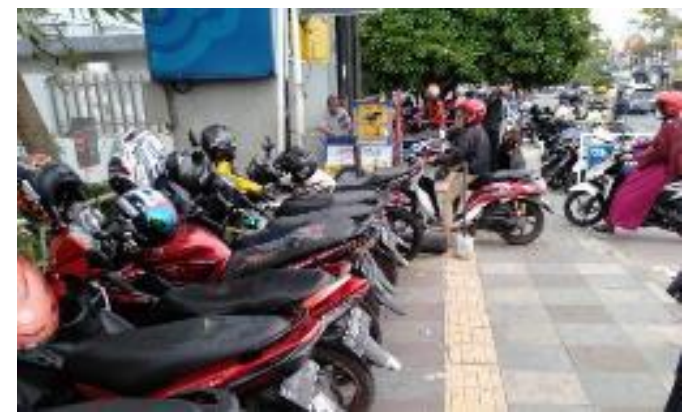

Gambar 16. Jalur Pejalan Kaki yang Digunakan Untuk Parkir Kendaraan (belum baik) Sumber : Hasil Survei 2019

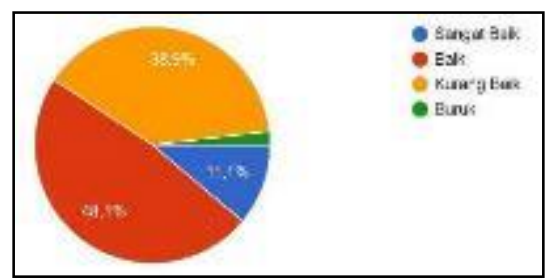

Diagram Pie 7. Persentase Masyarakat yang Memberi Tanggapan Tetang Pedestrian Ways Sumber : Hasil Analisis 2019

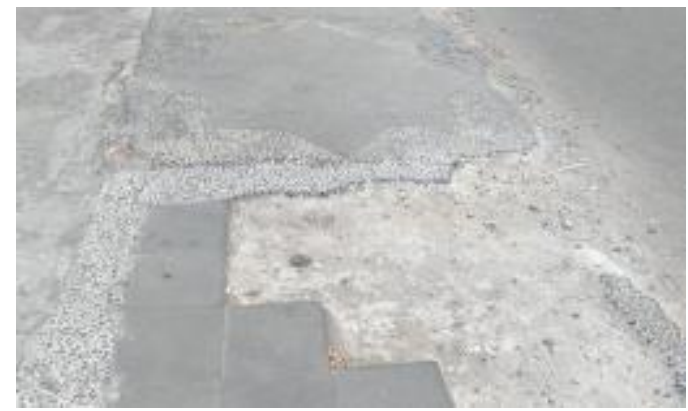

Gambar 17. Jalur Pejalan Kaki yang Masih Rusak (belum baik)

Sumber : Hasil Analisis 2019

Saat ini kondisi jalur pejalan kaki sudah baik karena telah direnovasi pada tahun 2018. Jalur pejalan kaki sudah dilengkapi dengan jalur khusus untuk penyandang tuna netra. 


\section{Analisis Signages}

Analisis persepsi masyarakat terhadap papan penanda (Signages) yang ada di Koridor Jalan Cipto Mangunkusumo yaitu sebesar 59, 5\% dari populasi masyarakat berpendapat bahwa kondisi dan penataan papan penanda yang ada di koridor jalan tersebut sudah baik.

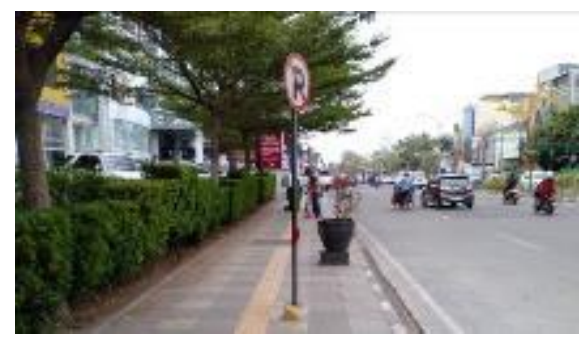

Gambar 18. Papan Penanda Rambu Jalan (sudah baik)

Sumber : Hasil Survei 2019

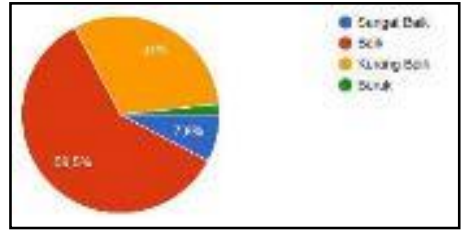

Diagram Pie 8. Persentase Masyarakat yang Memberi Tanggapan Tetang Signages Sumber : Hasil Analisis 2019

Hasil tersebut didapatkan karena Jalan Cipto Mangunkusumo merupakan jalan alteri kota sehingga perletakkan dan keberadaan penanda jalan sangat diutamakan. Tetapi penataan penanda untuk tujuan komersial dan publikasi seperti baliho iklan di beberapa sudut tertentu masih bertumpukan dan belum tertata rapi.

\section{Analisis Activity Support}

Analisis persepsi masyarakat terhadap Activity Support yang ada di Koridor Jalan Cipto Mangunkusumo yaitu sebesar $\mathbf{4 8 , 3 \%}$ dari populasi masyarakat berpendapat bahwa ruang pendukung aktivitas yang ada di koridor jalan tersebut kurang baik.

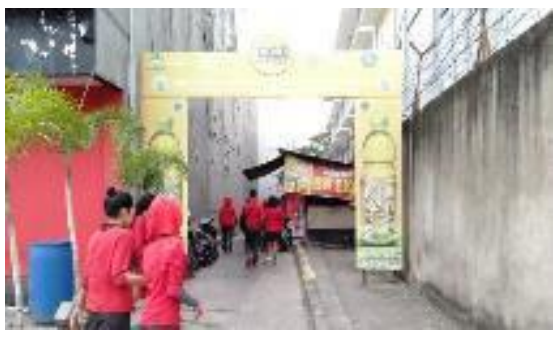

Gambar 19. Area lokasi khusus PKL (sudah baik)

Sumber : Hasil Survei 2019

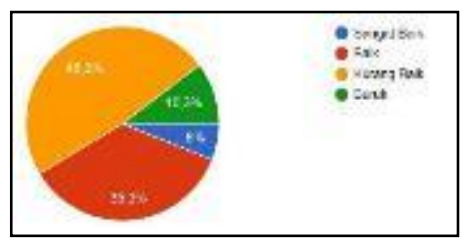

Diagram Pie 9. Persentase Masyarakat yang Memberi Tanggapan Tetang Activity Support Sumber : Hasil Analisis 2019

Hasil tersebut didapat karena ketersediaan area aktivitas pendukung kegiatan yang ada di Jalan Cipto Mangunkusumo belum tersedia secara jelas, seperti ruang terbuka khusus kegiatan. Akan tetapi ketersediaan area atau lokasi untuk untuk PKL sudah tersedia dengan baik.

\section{Analisis Preservation}

Analisis persepsi masyarakat terhadap preservasi (Preservation) yang ada di Koridor Jalan Cipto Mangunkusumo yaitu sebesar $67,2 \%$ dari populasi masyarakat berpendapat bahwa preservasi yang ada di koridor jalan tersebut sudah baik.

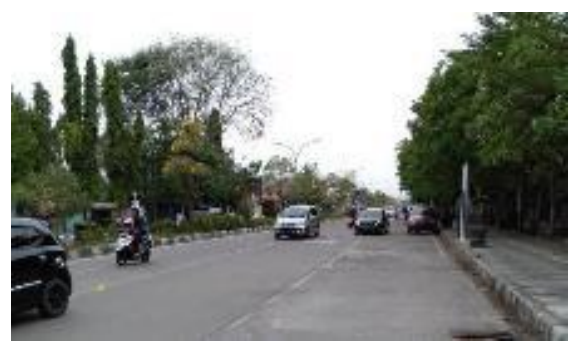

Gambar 20. Preservasi di Koridor Jalan Jalan Cipto Mangunkusumo (sudah baik) Sumber : Hasil Survei 2019

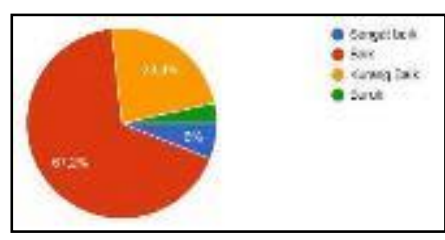

Diagram Pie 10. Persentase Masyarakat yang Memberi Tanggapan Tetang Preservation Sumber : Hasil Analisis 2019 
Hasil tersebut didapat karena preservasi yang ada di Koridor Jalan Cipto Mangunkusumo sudah baik, seperti perawatan terhadap area publik dan beberapa elemen pembentuk kota yang ada di koridor jalan tersebut.

\section{SIMPULAN}

Berdasarkan hasil analisis terhadap 8 elemen fisik pembentuk kota yang ada di Koridor Jalan Cipto Mangunkusumo Kota Cirebon sebagian besar sudah baik. Elemen fisik pembentuk kota yang sudah baik atau sesuai dengan peruntukannya antara lain:

- Penggunaan lahan/ Land Use $(61,2 \%)$

- Bentuk dan massa bangunan/ Building Form and Massing $(67,2 \%)$

- Jalur pejalan kaki/ Pedestrian Ways $(48,1 \%)$

- Papan penanda/ Signage $(59,5 \%)$

- Preservasi/ Preservation $(67,2 \%)$

Namun ada beberapa elemen fisik pembentuk kota yang masih belum baik. Hal ini disebabkan karena meningkatnya aktivitas masyarakat yang ada di koridor jalan tersebut yang berpengaruh terhadap kepadatan arus lalu lintas. Hal ini dikarenakan lokasi koridor berdekatan dengan sekolah, pusat perbelanjaan dan tempat kuliner.

Adapun elemen fisik pembentuk kota yang belum baik atau kurang sesuai antara lain:

- Sirkulasi dan area parkir/ Circulation and Parking $(56,9 \%)$

- Ruang terbuka/ Open Space $(53,4 \%)$

- Ruang pendukung aktivitas/ Activity Support $(48,3 \%)$

Elemen fisik pembentuk kota mempunyai potensi untuk menambah nilai kemajuan kota oleh karenanya perlu diperhatikan dan ditingkatkan. Meningkat aktivitas masyarakat berbanding lurus dengan ketersediaan sarana dan prasarana publik karena mempunyai pengaruh terhadap kenyamanan. Oleh karenanya dituntut kesadaran masyarakat untuk menjaga dan merawat fasilitas yang sudah ada demi kelancaran keberlangsungan aktivitas masyarakat di kawasan kota tersebut.

\section{DAFTAR PUSTAKA}

[1] Badan Pusat Statistik Kota Cirebon, Cirebon Dalam Angka. Jumlah kendaraan dalam kurun waktu 3 tahun sebelumnya. 2018.

[2] Sugiyono, Metode Penelitian Pendidikan, Pendekatan Kuantitatif, Kualitatif, dan R\&D. Alfabeta. Bandung. 2016.

[3] H. Shirvani, The Urban Design Process. Van Nostrand Reinhold Company, Newyork. 1985.

[4] N.W. Marler, Transport Planning, Materi Kuliah Pasca Sarjana Planologi Institut Teknologi Bandung. Bandung. 1985.

[5] F. D.K. Ching, Teori Arsitektur : Bentuk, ruang, dan susunannya, Jakarta, Erlangga. 1993.

[6] Y. Ashihara, Exterior Design in Architecture. Van Nostrand Reinhold, Revised ed. Edition. 1981.

[7] A. Abdillah, Penelitian Arsitektur Sirkulasi dan Parkir. Jurnal Fakultas Teknik, Program Studi Arsitektur. Universitas Krisna Dwipayana. 2017.

[8] R. Hakim, Komponen Perancangan Arsitektur Lanskap: Prinsip - unsur dan aplikasi disain. Jakarta, Bumi Aksara. 2012.

[9] A. Adinugrah, Rahnandahegar, Persepsi dan Preferensi Masyarakat Tentang Aspek Perancangan Kota Dalam Upaya Pelestarian Kota Lama Tangerang. Jurnal Teknik Perencanaan Wilayah dan Kota, Universitas Komputer Indonesia. 2013.

[10] Badan Pusat Statistik Kota Cirebon, Cirebon Dalam Angka. Gambaran Umum Wilayah Kota Cirebon. 2018. 